\title{
ANALISIS STRATEGI MEMBANGUN BRAND AWARENESS E- COMMERCE SHOPEE DI MEDIA SOSIAL DALAM MENINGKATKAN PENJUALAN
}

\author{
Machella Shevany \\ Universitas Islam Negeri Sunan Ampel Surabaya \\ mshevany@gmail.com
}

\begin{abstract}
The increasingly rapid development of e-commerce makes competition even more stringent. Businesses are also required to compete competitively to retain consumers, one of which is by building brand awareness in the minds of consumers. Companies that have strong brands are certainly easily recognized by the public and can survive amid intense competition. For this reason, shopees need to implement effective strategies to build brand awareness. In building its brand awareness, shopee not only does marketing through its platform, but also applies marketing strategies through social media that are useful as a means to further expand market reach. This research use descriptive qualitative by literature study sourced from books, journals, and related web to research topics. The conclusion is that the strategy to build brand awareness in social media is very effective because it is easy to access and many people use social media in their activities. The use of effective shopee marketing strategies through social media makes it able to shift its competitors and reach the top position of brand awareness in Indonesia. The increase in brand awareness has made shopees more widely known and the sales have increased.
\end{abstract}

Keywords: brand awareness ; e-commerce ; sales ; social media

\section{PENDAHULUAN}

Perkembangan teknologi yang semakin canggih membuat aktivitas sehari-hari menjadi lebih mudah. Dengan menggunakan handphone saja, seseorang bisa mengakses sesuatu dengan cepat, praktis, dan mudah. Perkembangan teknologi saat ini tentu membawa dampak positif terutama bagi pelaku bisnis. Aktivitas jual beli yang dulunya dilakukan secara tradisional dengan melakukan tatap muka langsung, sekarang menjadi semakin mudah tanpa harus keluar rumah. Selain itu, penjualan yang dilakukan tidak terbatas pada suatu daerah saja, namun dapat melakukan penjualan dengan jangkauan yang sangat luas. Berdasarkan data yang dikutip dari laman detik.com, laporan dari wearesocial menunjukkan bahwa di Indonesia, pengguna internet per Januari 2020 mencapai 175,4 juta pengguna dan untuk pengguna yang aktif dalam media sosial sebesar 160 juta pengguna. Hal tersebut menunjukkan bahwa penggunaan internet dan pengguna yang aktif media sosial di Indonesia terbilang tinggi sehingga para pelaku bisnis menjadi tertarik untuk memanfaatkan peluang tersebut.

Penggunaan teknologi yang canggih tersebut merupakan suatu peluang bagi bisnis yang harus dimanfaatkan penggunaannya. Salah satunya yaitu menciptakan peluang 
perdagangan secara online atau biasa kita kenal dengan e-commerce. E-commerce merupakan penggunaan jaringan komunikasi untuk melaksanakan bisnis. Dengan melakukan perdagangan secara online, penjual lebih mudah memasarkan produknya dengan jangkauan pembeli yang luas. Selain itu, pembeli cukup melakukan pembelian secara online, barang bisa dikirim tanpa harus keluar rumah. Kemudahan tersebut tentu membuat seseorang lebih suka melakukan pembelian melalui online.

Perkembangan e-commerce yang semakin pesat membuat persaingan juga semakin ketat. Hal tersebut mendorong pelaku bisnis dibidang ini untuk melakukan pemasaran yang efektif sehingga produk dapat dikenal dan dapat bertahan di pasaran. Selain itu, pelaku bisnis juga dituntut bersaing secara kompetitif untuk mempertahankan konsumen, salah satunya yaitu dengan membangun brand awareness atau kesadaran merek dibenak konsumen. Setiap perusahaan pasti berusaha menjadikan merek mereka sebagai merek yang terbaik untuk semakin memperkuat serta memperluas bisnisnya. Banyaknya pesaing yang semakin banyak membuat Shopee sebagai bisnis yang bergerak dibidang e-commerce juga harus menentukan strategi pemasaran yang efektif sehingga dapat bersaing dan bertahan di pasaran. Shopee merupakan salah satu e-commerce berbasis marketplace terbesar di Indonesia. Pada awal berdirinya, kesadaran masyarakat akan merek shopee masih terbilang rendah. Oleh karena itu, penting untuk membangun brand awareness sehingga dapat menjadi top of mind dibenak konsumen.

Merek adalah hal yang menjadi aset penting bagi suatu perushaan. Perusahaan yang memiliki merek yang kuat tentu mudah dikenal oleh masyarakat dan dapat bertahan ditengah ketatnya persaingan. Menurut Temporal dan Lee, merek adalah suatu hal yang penting yang dapat mempermudah dalam penentuan pilihan, pencegahan risiko, serta jaminan kualitas. Dalam membangun brand awarenessnya, shopee tidak hanya melakukan branding melalui platformnya, namun juga menggunakan media sosial seperti facebook, instagram, twitter, youtube, dan tik tok. Hal tersebut efektif dilakukan karena biaya yang dikeluarkan tidak terlalu besar dan dapat menjangkau konsumen lebih luas. Kesuksesan shopee membangun brand awareness membuatnya semakin populer dikalangan masyarakat sehingga penjualan juga semakin meningkat. Meskipun telah sukses berada di posisi teratas, Shopee harus selalu melakukan berbagai strategi yang inovatif untuk mempertahankan posisinya mengingat banyaknya kompetitor. Berdasarkan uraian tersebut, peneliti tertarik untuk mengetahui bagaimana strategi membangun brand awareness e-commerce shopee di media sosial dalam meningkatkan penjualan.

\section{METODE PENELITIAN}

Metode penelitian yang digunakan yaitu metode deskriptif kualitatif dengan menggunakan studi pustaka atau literatur yang bersumber dari buku, jurnal, dan web yang terkait dengan topik penelitian. 


\section{PEMBAHASAN}

\section{E-Commerce}

E-commerce merupakan salah satu industri yang mengalami pertumbuhan yang pesat. Menurut Turban, e-commerce merupakan pertukaran produk, informasi, serta layanan lewat jaringan internet. Sedangkan menurut Andam dan Loudon, ecommerce merupakan penggunaan komunikasi elektronik dan teknologi informasi digital dalam melakukan transaksi bisnis untuk menciptakan, mentransformasikan, serta mendefinisikan kembali hubungan untuk penciptaan nilai diantara penjual dan pembeli. Dapat disimpulkan bahwa e-commerce merupakan aktivitas perdagangan yang menggunakan teknologi informasi secara online. E-commerce terbagi menjadi lima jenis, yaitu :

a. Business to Business E-Commerce

Merupakan perdagangan secara online dimana transaksi dilakukan antar perusahaan. Contoh penerapan jenis ini yaitu pada e-commerce Bizzy yang menyediakan kebutuhan bagi perusahaan yang bermasalah dalam hal pengadaan persediaan bisnis, salah satunya yaitu menyediakan kebutuhan persediaan alat tulis kantor.

b. Business to Consumer E-Commerce

Merupakan perdagangan online antara perusahaan dengan konsumen. Jenis ecommerce ini digunakan oleh perusahaan yang melakukan penjualan kepada konsumen secara langsung dengan mengelola situs sendiri. Contohnya seperti tiket.com yang menjual berbagai tiket perjalanan langsung kepada konsumen.

c. Consumer to Consumer E- Commerce

Merupakan jenis perdagangan secara online antar konsumen. Jenis e-commerce ini biasanya menggunakan pihak ketiga sebagai penyedia platform digital. Contohnya seperti shopee yang menyediakan platform dimana penjual bisa langsung memasarkan produknya kepada konsumen. Dengan menggunakan pihak ketiga, konsumen akan lebih aman dalam melakukan transaksi karena sistemnya menggunakan rekening bersama yang meminimalisir tindakan penipuan.

d. Consumer to Business E- Commerce

Merupakan jenis perdagangan secara online dimana konsumen merupakan penjualnya dan perusahaan bertindak sebagai pembeli. Contohnya seperti My Blogger Themes yang menyediakan berbagai template dari para pengembang template. Para pengembang dapat mengunggah template yang dibuat ke link yang disediakan dan selanjutnya pihak perusahaan akan menjualnya di website dimana nanti akan menggunakan sistem bagi hasil.

e. Business to Government

Merupakan jenis perdagangan secara online antara perusahaan dan pemerintah. Terdapat tiga elemen dalam jenis ini yang meliputi pemerintah, website, dan perusahaan. Pemerintah harus menggunakan perantara website sebagai penghubung ke perusahaan. Contohnya seperti kegiatan lelang yang diselenggarakan oleh pemerintah kepada berbagai perusahaan yang dilakukan secara online. Selain itu ada juga kegiatan tender proyek yang dilakukan 
pemerintah secara online dimana perusahaan yang berhasil memenangkan hal tersebut akan diajak bekerja sama sesuai dengan kesepakatan.

\section{Media Sosial}

Media sosial merupakan teknologi dengan menggunakan internet yang menjadi sarana percakapan. Media sosial menggambarkan berbagai sumber informasi baru secara online yang digunakan konsumen untuk tujuan mengedukasi mengenai merek, produk, keperibadian, jasa, dan isu-isu yang relevan. Media sosial dikelompokkan menjadi lima macam, yaitu :

a. Egocentric Sites

Egocentric Sites merupakan situs yang memungkinkan penggunanya membuat profil sehingga dapat memfasilitasi koneksi identitas. Contohnya seperti Facebook dan Myspace.

b. Community Sites

Community Sites merupakan situs yang mengimitasi komunitas dalam dunia nyata sehingga dapat memungkinkan terbentuknya kelompok-kelompok tertentu. Contohnya seperti situs Bigwavedave dan Dogster.

c. Opportunistic Sites

Opportunistic Sites merupakan situs yang memungkinkan terbentuknya berbagai organisasi sosial serta memfasilitasi dalam koneksi bisnis. Contohnya seperti Linkedln dan Academi.edu.

d. Passion Centric Sites

Passion Centric Sites merupakan situs yang memungkinkan para penggunanya berhubungan berdasarkan minat dan hobi. Contohnya seperti situs Thesamba dan Chatterbirds.

e. Media Sharing Sites

Media Sharing Sites merupakan situs yang memungkinkan penggunanya untuk saling berbagi media, baik berupa gambar, audio, dan video. Contohnya seperti Youtube, Instagram, Tik Tok, dan Slideshare

Media sosial harus dimanfaatkan secara efektif terutama oleh pelaku bisnis karena memiliki dua peran promosi terkait yaitu memungkinkan perusahaan berkomunikasi dengan pelanggan dan dapat dimanfaatkan pelanggan berkomunikasi dengan sesama pelanggan. Perusahaan dapat mengoptimalkan pemasarannya dengan menyediakan platform networking, menggunakan berbagai media sosial untuk membuat konsumen terlibat secara aktif dengan produk bisnis kita, serta menyediakan informasi relevan kepada pelanggan melalui media sosial.

\section{Brand Awareness}

Merek merupakan suatu simbol, nama, tanda, desain yang digunakan sebagai identitas perusahaan pada produknya untuk membedakannya dengan yang lainnya. Merek sangat diperlukan dalam suatu bisnis karena merek merupakan value bagi perusahaan dan memiliki beberapa manfaat seperti memudahkan proses pelacakan atau produk pada perusahaan, membuat mutu produk lebih terjamin, dan memberikan perlindungan hukum atas keunikan suatu produk. Dalam menciptakan merek, perusahaan harus memperhatikan kriteria dalam memilih elemen merek, yaitu : 
a. Mudah Diingat (Memorable) : Elemen merek seperti logo, nama, simbol yang digunakan harus dibuat dengan unik dan menarik sehingga mudah diingat yang menarik perhatian konsumen untuk selalu diingat dan dikonsumsi.

b. Bermakna (Meaningful) : Elemen merek hendaknya memiliki makna maupun penjelasan akan produk. Deskripsi makna dapat berupa informasi mengenai filosofi merek, informasi mengenai kategori dan isi dari produk, serta komposisi dan manfaat penting produk.

c. Fleksibel (Adaptibility) : Elemen merek hendaknya dapat dimengerti dan dapat diterima pasar bahkan budaya lainnya. Seringkali elemen merek mudah diingat masyarakat lokal itu sendiri tetapi sangat sulit dimengerti masyarakat lainnya. Hat tersebut tentu dapat menghambat suatu produsen masuk dalam pasar baru.

d. Menarik (Interesting) : Elemen merek hendaknya dibuat dengan variasi desain yang unik dan lucu. Pemilihan merek yang kaya akan desain visualisasi dan imajinasi akan membuat konsumen menjadi semakin tertarik.

e. Legal (Protectability) : Elemen merek yang digunakan legal dalam artian sah menurut hukum yang berlaku sehingga memiliki perlindungan dibawah hukum yang ada.

Semakin banyaknya persaingan menuntut perusahaan harus memiliki kekuatan merek dipasaran. Kekuatan merek yang dimiliki merupakan suatu pembeda dan bernilai yang akan menjadi kekuatan daya saing dengan pesaing lainnya. Oleh karena itu, perusahaan harus membangun brand awareness dibenak konsumen sehingga dapat memperkuat mereknya. Brand awareness merupakan kesanggupan konsumen dalam mengenali dan mengingat kembali akan suatu merek. Selain itu, brand awareness juga dapat didefinisikan sebagai pengakuan akan suatu merek dan pembeda dari merek lainnya. Semakin banyak konsumen yang memiliki kesadaran merek yang tinggi, maka semakin besar juga potensi pembelian yang dilakukan. Terdapat empat tingkatan dalam brand awareness, yaitu :

a. Unware of Brand : merupakan tingkatan yang paling rendah dimana konsumen tidak menyadari adanya suatu merek.

b. Brand Recognition : merupakan tingkat yang minimal dari brand awareness dimana konsumen mengenal suatu merek ketika melihatnya.

c. Brand Recall : merupakan kondisi dimana konsumen dapat mengingat suatu merek. Dalam tingkatan ini, konsumen mengingat tanpa bantuan karena mengandalkan memorinya sehingga tidak perlu adanya bantuan dalam memunculkan merek tersebut.

d. Top of Mind : merupakan puncak pikiran yang mengacu pada merek yang muncul pertama kali dibenak konsumen saat memikirkan kategori produk tertentu. Contohnya ketika ada yang bertanya merek air minum kemasan, maka secara spontan merek yang ada dibenak kita adalah Aqua. 


\section{Penjualan}

Penjualan merupakan kegiatan bisnis dalam menjual barang atau jasa. Dalam kehidupan ini, kita tentu tidak asing dengan jual beli. Kegiatan ini melibatkan seseorang yang bertindak menjual barang atau jasa yang disebut sebagai penjual dan juga pembeli yang bertindak sebagai seseorang yang melakukan pembelian. Penjualan terbagi menjadi dua jenis yaitu penjualan langsung dan penjualan tidak langsung. Penjualan langsung merupakan penjualan dimana penjual dan pembeli dapat bertatap muka secara langsung. Dalam jenis ini, penjual akan melakukan promosi langsung tanpa bantuan pihak lainnya. Sedangkan penjualan tidak langsung merupakan kegiatan penjualan yang menggunakan perantara untuk mempromosikan suatu produk kepada konsumen. Media perantara yang digunakan biasanya melalui internet, iklan, atau katalog online. Kegiatan penjualan dipengaruhi oleh beberapa faktor yang perlu diperhatikan diantaranya yaitu :

- Kondisi Pasar : Pasar merupakan sekelompok pembeli yang potensial. Dalam hal ini, yang perlu diperhatikan yaitu seperti jenis pasar, kebutuhan pasar, segmen pasar, kelompok pembeli, daya beli, dan frekuensi pembelian.

- Modal : Penjualan akan sulit jika pembeli belum mengenal produk kita. Oleh karena itu penjual harus memperhatikan modal dalam melakukan penjualan seperti biaya untuk promosi dan alat transportasi untuk kegiatan operasional.

- Kondisi Perusahaan : Perusahaan berskala besar biasanya menyelesaikan masalah terkait penjualan dengan ditangani oleh divisi penjualan yang dilakukan oleh para ahli dibidang tersebut.

- Promosi : merupakan kegiatan menawarkan produk pada konsumen. Faktor yang mempengaruhi penjualan dalam promosi seperti periklanan, pemberian reward, dan peragaan promosi.

Perusahaan tentu melakukan penjualan untuk suatu tujuan, salah satunya yaitu untuk mendapatkan keuntungan. Berhasilnya kegiatan pemasaran yang kita lakukan yaitu adanya peningkatan penjualan yang dapat kita lihat dari indikator target penjualan yang tercapai, laba yang didapat, dan pertumbuhan perusahaan. Semakin besar tingkat penjualan yang dilakukan, maka semakin besar pula kemungkinan keuntungan yang didapat oleh perusahaan.

\section{Strategi Membangun Brand Awareness Shopee di Media Sosial}

Strategi merupakan pola atau rencana yang disusun guna mencapai tujuan sehingga mampu bersaing dengan para pesaing yang lainnya. Sedangkan dalam konteks strategi pemasaran dapat diartikan sebagai berbagai upaya yang dilakukan oleh suatu perusahaan memasarkan produknya dengan menggunakan taktik atau pola rencana tertentu sehingga membuat jumlah penjualan menjadi meningkat. 
Shopee merupakan salah satu perdagangan online terbesar di Indonesia yang didirikan pada tahun 2015. Pada awal kemunculannya, tentu shopee tidak terlalu terkenal di kalangan masyarakat luas. Oleh karena itu, shopee melakukan berbagai strategi salah satunya yaitu strategi pemasaran di media sosial guna membangun brand awareness pada konsumen. Hal tersebut membuat shopee mampu untuk menggeser para pesaingnya yang sudah terlebih dahulu berkecimpung di dunia ecommerce dan juga menjadi top e-commerce di Indonesia. Shopee menggunakan berbagai platform media sosial untuk menunjang kegiatan pemasarannya mulai dari instagram, facebook, youtube, twitter, hingga tik tok. Dengan melakukan pemasaran melalui media sosial, shopee dapat menghemat biaya marketing dan dapat menjangkau konsumen lebih luas. Adapun strategi yang dilakukan shopee untuk membangun brand awareness di media sosial diantaranya yaitu :

a. Menyajikan Iklan Berdasarkan Tren

Dalam melakukan iklan, shopee membuat konten berdasarkan trend yang ada.

Hal tersebut membuat konsumen menjadi lebih mudah mengingat brand dari shopee itu sendiri. Media yang digunakan shopee untuk memasang iklan salah satunya yaitu dengan menggunakan media sosial youtube, mengingat sekarang banyak masyarakat banyak beralih menggunakan youtube daripada televisi. Salah satu contohnya ketika pada tahun 2016 sedang trend lagu baby shark, shopee membuat iklan "di shopee pi pi pi" dengan menggunakan nada baby shark. Tercatat bahwa penonton iklan tersebut di akun youtube milik shopee mencapai 2,4 juta penonton. Strategi ini tentu dapat menarik minat konsumen untuk semakin memiliki kesadaran akan merek shopee.

b. Melakukan Banyak Promosi

Shopee melakukan berbagai promosi sehingga konsumen menjadi tertarik melakukan pembelian. Salah satu promosi yang ditawarkan shopee hingga saat ini yaitu promo gratis ongkir dimana konsumen tidak perlu untuk membayar ongkir atas barang yang dibelinya. Promo gratis ongkir diberikan sesuai syarat dan ketentuan yang berlaku. Shopee selalu memberikan informasi terkait promo yang akan diadakan melalui media sosial baik itu instagram, twitter, facebook, youtube, dan tik tok guna mengingatkan kembali kepada konsumen. Dengan banyaknya promo yang ditawarkan, tentu shopee akan membuat konsumen mudah mengingat bahwa merek e-commerce yang murah dan banyak promonya adalah shopee. Strategi ini memungkinkan penjualan semakin meningkat karena memiliki daya tarik yang tinggi bagi konsumen untuk melakukan pembelian.

c. Mengadakan Giveaway

Mengadakan giveaway merupakan cara efektif yang dapat digunakan untuk semakin meningkatkan kesadaran akan merek. Dalam hal ini, shopee selalu mengadakan giveaway setiap minggunya yang membuat konsumen akan membuka platform dan media sosial shopee untuk mengikutinya. Salah satunya 
adalah giveaway Shopee Tanam THR 10M yang berhadiah Iphone 11. Untuk mengikuti giveaway tersebut, konsumen harus menanam pohon THR melalui platform shopee dan mengunggah hasil panennya di media sosial seperti facebook, twitter, dan instagram. Selain itu, peserta juga diharuskan menggunakan hastag \#shopeetanamthr10m dan \#shopeedarirumah setiap kali menggunggah foto hasil panen shopee tanam. Semakin banyak hastag tersebut digunakan dalam suatu postingan, maka hal tersebut akan menjadi trending dan dapat meningkatkan popularitas di media sosial.

d. Menggunakan Brand Ambassador

Brand ambassador merupakan seseorang yang dipilih untuk mempromosikan suatu merek. Shopee memanfaatkan peluang dengan memasang iklan di media sosial dengan menggunakan brand ambassador. Salah satu brand ambassador yang digunakan yaitu Didi Kempot, yang merupakan seorang seniman yang legendaris dan memiliki banyak fans yang terkenal dengan nama sobat ambyar. Alasan shopee menggunakan didi kempot sebagai brand ambasadornya yaitu karena fans yang dimiliki sangat banyak dan memiliki antusias tinggi dan juga karena sejalan dengan visi misi shopee terkait dengan kesadaran akan keragaman budaya di Indonesia. Penggunaan brand ambassador dapat bermanfaat untuk semakin meningkatkan brand awareness karena memiliki pengaruh yang besar yang dapat mempengaruhi konsumen melakukan pembelian. Dapat kita lihat dalam iklan berjudul Shoppe Men Sale bersama Didi Kempot dalam media sosial youtube menunjukkan bahwa jumlah penonton iklan tersebut lebih tinggi jika dibandingkan iklan lainnya yaitu mencapai 5,2 juta penonton.

Strategi membangun brand awareness di media sosial sangatlah efektif dilakukan mengingat kemudahan akses dalam menjangkau konsumennya. Konsistensi shopee melakukan promosi secara rutin di media sosial membuat shopee mampu mencapai posisi top of mind e-commerce di Indonesia. Berdasarkan survei yang dilakukan oleh Mark Plus mengenai brand awareness para e-commerce di Indonesia, tercatat bahwa top of mind merek pada tahun 2018 diraih oleh shopee yaitu sebesar $31 \%$. Pada tahun 2019, Mark Plus kembali melakukan survey mengenai wanita dan ecommerce. Berdasarkan hasil survei tersebut, shopee meraih posisi pertama yaitu sebesar 56\% sebagai e-commerce yang pertama kali muncul dibenak konsumen perempuan. Semakin meningkatnya brand awareness, tentu shopee semakin dikenal di masyarakat. Hal tersebut tentu juga berdampak pada peningkatan penjualan. Data menunjukkan bahwa pada tahun 2017, shopee telah melayani sebanyak 244,8 juta pesanan dan mengalami peningkatan drastis menjadi sebanyak 604,5 juta pesanan. Hal Meskipun telah berada pada posisi teratas, tentu shopee harus tetap melakukan berbagai strategi yang efektif agar dapat bertahan ditengah ketatnya persaingan. 


\section{KESIMPULAN}

E-commerce merupakan perdagangan elektronik yang menggunakan jaringan komunikasi untuk melaksanakan bisnis. Dengan melakukan perdagangan secara online, penjual lebih mudah memasarkan produknya dengan jangkauan pembeli yang luas. Selain itu, pembeli cukup melakukan pembelian secara online, barang bisa dikirim tanpa harus keluar rumah.

Media sosial merupakan teknologi berbasis internet yang menjadi sarana percakapan untuk semakin memperluas jangkauan konsumen. Media sosial harus dimanfaatkan secara efektif terutama oleh pelaku bisnis karena media sosial memiliki dua peran promosi terkait yaitu memungkinkan perusahaan berkomunikasi dengan pelanggan dan dapat dimanfaatkan pelanggan berkomunikasi dengan sesama pelanggan.

Merek merupakan suatu simbol, nama, tanda, desain yang digunakan sebagai identitas perusahaan pada produknya untuk membedakannya dengan yang lainnya. Perusahaan yang memiliki merek yang kuat tentu mudah dikenal oleh masyarakat dan dapat bertahan ditengah ketatnya persaingan. Untuk itu, perusahaan perlu untuk membangun brand awareness di benak konsumen sehingga dapat memperkuat merek. Brand awareness merupakan kesanggupan konsumen mengenali dan mengingat kembali akan suatu merek. Brand awareness terbagi menjadi menjadi empat tingkatan yaitu Unware of Brand (Tidak Mengenali Merek), Brand Recognition (Mengenal Merek), Brand Recall (Mengingat Merek), dan Top of Mind (Puncak Pikiran).

Penjualan merupakan kegiatan bisnis dalam menjual barang atau jasa. Berhasilnya kegiatan pemasaran yang kita lakukan yaitu adanya peningkatan penjualan yang dapat kita lihat dari indikator target penjualan yang tercapai, laba yang didapat, dan pertumbuhan perusahaan. Tingkat penjualan yang semakin besar akan memungkinkan perusahaan untuk mendapat laba yang lebih besar pula.

Strategi membangun brand awareness di media sosial sangat efektif digunakan karena mudahnya akses dan banyak masyarakat yang menggunakan media sosial dalam aktivitasnya. Shopee melakukan berbagai strategi untuk membangun brand awareness nya di media sosial seperti menyajikan iklan berdasarkan tren, melakukan banyak promosi, sering mengadakan giveaway, dan menggunakan brand ambassador. Penggunaan strategi pemasaran shopee yang efektif melalui media sosial membuatnya mampu menggeser pesaingnya dan dapat meraih posisi teratas brand awareness di Indonesia. Peningkatan brand awareness tersebut membuat shopee semakin terkenal dan penjualan juga menjadi semakin meningkat. 


\section{DAFTAR PUSTAKA}

Anggraini, C. A., Perbawasari, S., \& Budiana, H. R. (2018). Cyberbranding Sebagai Upaya Membangun Brand Awareness Shopee Indonesia. Jurnal Komunikasi Dan Media. 2(2): 72.

Pradana, M. (2015). Klasifikasi Jenis-Jenis Bisnis E-Commerce. Jurnal Neo-Bis. 9(2): $32-40$.

Srisadono, Wahyu. (2018). Strategi Perusahaan E-Commerce Membangun Brand Community di Media Sosial Dalam Meningkatkan Omset Penjualan. Jurnal Pustaka Komunikasi. 1(1): 167-179.

Febriyan. \& Supriono, S. (2018). Pengaruh Pemasaran Media Sosial Terhadap Brand Awareness Pada Produk Internasional. Jurnal Administrasi Bisnis. 61(1): 74-79.

Herdana, A. (2015). Analisis Pengaruh Kesadaran Merek Pada Produk Asuransi Jiwa Prudential Life Assurance (Studi Pada Pru Passion Agency Jakarta). Jurnal Riset Bisnis Dan Manajemen. 3(1): 1-18.

Maulana, S. M., Susilo, H., \& Riyadi. (2015). Implementasi E-Commerce Sebagai Media Penjualan Online. Jurnal Administrasi Bisnis. 29(1): 1-9.

Firmansyah, Anang. (2019). Pemasaran Produk dan Merek. Pasuruan : Qiara Media.

Tjiptono, Fandy. (2015). Strategi Pemasaran. Yogyakarta: ANDI.

Sumarwan, Ujang dkk. (2010). Pemasaran Strategik. Bogor : IPB Press.

Setiyaningrum, Ari dkk. (2015). Prinsip-Prinsip Pemasaran. Yogyakarta: ANDI.

Shinta, Agustina. (2011). Manajemen Pemasaran. Malang : UB Press.

Haryanto, Agus Tri (2018). Riset : Ada 175,2 Juta Pengguna Internet di Indonesia. Detik.com.( https://inet.detik.com/cyberlife/d-4907674/riset-ada-1752-jutapen gguna-internet-di-indonesia\#, diakses pada 13 Mei 2018).

Syarizka, Deandra. (2018). Shopee Layani 900.000 Order Per Hari di Indonesia.Teknologi.com.(https://teknologi.bisnis.com/read/20190304/266/895 740/shopee-layani-900.000-order-per-hari-di-indonesia, diakses pada 15 Mei 2018) 